\title{
Refuge
}

Canada's Journal on Refugees

revue canadienne sur les réfugiés

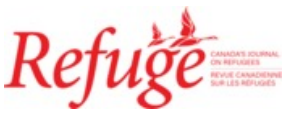

\section{"We" the Refugees: Reflections on Refugee Labels and Identities}

\section{Yanery Navarro Vigil et Catherine Baillie Abidi}

Volume 34, numéro 2, 2018

URI : https://id.erudit.org/iderudit/1055576ar

DOI : https://doi.org/10.7202/1055576ar

Aller au sommaire du numéro

\section{Éditeur(s)}

Centre for Refugee Studies, York University

ISSN

0229-5113 (imprimé)

1920-7336 (numérique)

Découvrir la revue

Citer cet article

Vigil, Y. \& Baillie Abidi, C. (2018). "We” the Refugees: Reflections on Refugee Labels and Identities. Refuge, 34(2), 52-60. https://doi.org/10.7202/1055576ar
Résumé de l'article

Les auteurs présentent dans cet article une analyse auto-ethnographique fondée sur la description de leurs vécus respectifs de la migration forcée. Par des extraits narratifs, ils problématisent la manière dont les identités de réfugiés sont liées à des catégories socialement construites. Ils explorent les points de négociation entre l'auto-identifcation et la catégorisation pour créer de nouveaux espaces dans lesquels les expériences individuelles et collectives de réfugiés se façonnent mutuellement et se transforment les unes les autres. Ces nouveaux espaces se dégagent à partir d'un processus participatif et inclusif qui relève à la fois du politique et du socioculturel, dans lequel les concepts de " nous-mêmes " et " eux " se fondent en une seule entité, " nous ". Cet article, qui est l'aboutissement d'interactions approfondies entre les auteurs (sous la forme de conversations, d'histoires racontées, d'analyses partagées, de textes rédigés), constitue un exemple de mise en action d'un nouvel espace.
Copyright (c) Refuge: Canada's Journal on Refugees, 2018

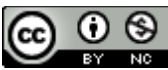

Ce document est protégé par la loi sur le droit d'auteur. L'utilisation des services d'Érudit (y compris la reproduction) est assujettie à sa politique d'utilisation que vous pouvez consulter en ligne.

https://apropos.erudit.org/fr/usagers/politique-dutilisation/ 


\title{
"We" the Refugees: \\ Reflections on Refugee Labels and Identities
}

\author{
YANERY NAVARRO VIGIL AND CATHERINE BAILLIE ABIDI
}

\section{Abstract}

In this article the authors present an auto-ethnographical analysis, describing their personal experiences with forced migration. Using narrative passages, the authors problematize the way in which refugee identities are entwined with socially constructed labels. The authors explore the points at which self-identification negotiates with labelling in order to create new spaces wherein individual and collective refugee experiences mutually shape and transform each other. These new spaces emerge from an inclusive participatory socio-cultural and political process where the idea of "us" and "them" merges into a "we." This article represents the culmination of the authors' sustained interactions (in conversation, in storytelling, in shared analyses, in writing) and serves as an example of putting a new space into action.

\section{Résumé}

Les auteurs présentent dans cet article une analyse autoethnographique fondée sur la description de leurs vécus respectifs de la migration forcée. Par des extraits narratifs, ils problématisent la manière dont les identités de réfugiés sont liées à des catégories socialement construites. Ils explorent les points de négociation entre l'auto-identification et la catégorisation pour créer de nouveaux espaces dans lesquels les expériences individuelles et collectives de réfugiés se façonnent mutuellement et se transforment les unes les autres. Ces nouveaux espaces se dégagent à partir d'un processus participatif et inclusif qui relève à la fois du politique et du socioculturel, dans lequel les concepts de "nousmêmes» et "eux» se fondent en une seule entité, "nous». Cet article, qui est l'aboutissement d'interactions approfondies entre les auteurs (sous la forme de conversations, d'histoires racontées, d'analyses partagées, de textes rédigés), constitue un exemple de mise en action d'un nouvel espace.

\section{Our Stories}

Y ANERY. I am a refugee. It is almost a decade since that event took place, the event that marked the beginning of the catastrophe that is intimately related with why I became a refugee-a catastrophe that violently forced me to leave my home. I came to Halifax (Nova Scotia, Canada) as an asylum-seeker and, after five years, gained refugee status in 2013. To situate my story, please accept the following poem, "The House That Was a Home." (c) Yanery Navarro Vigil and Catherine Baillie Abidi, 2018. This open-access work is licensed under a Creative Commons Attribution-NonCommercial 4.0 International Licence, which permits use, reproduction, and distribution in any medium for non-commercial purposes, provided the original authorship is credited and the original publication in Refuge: Canada's Journal on Refugees is cited.
Cette œuvre en libre accès fait lobjet d'une licence Creative Commons Attribution-NonCommercial 4.o International License, laquelle autorise l'utilisation, la reproduction et la distribution de l’ouvre sur tout support à des fins non commerciales, pourvu que l'auteur ou les auteurs originaux soient mentionnés et que la publication originale dans Refuge: revue canadienne sur les réfugiés soit citée. 
To F \& H

The house was empty. We were living for a week in the cottage. A turbulent dream woke me up, indicating he was there.

They are moving the furniture, taking the paintings, destroying the art that for years lay resting on the walls, books on boxes, more and more boxes running and running everywhere. Simply dispossessing you from your toys, your dolls, your games, your rooms.

The garden in silence is the only witness. I decided to stop my dream and intended to sleep.

At six a.m. my instinct shook me again and sent me home. I drove for more than two hours. When I tried to open the garage door, it was disconnected. I forced the door and crossed the entrance.

Are you here? I asked ... Silence ... the only witness replies, No! nobody is here.

You can continue ...

... with panic in my gloomy body, I asked again. Are you here? I observe that no one is even resting in the custodian's room.

Can you hear me ...?

I can continue,... the house is totally empty.

He put us out.

Now is time; this imposed the reality; we are looking for shelter.

It was not a robbery; it was a predetermined act of eviction, a demolition.

The decision was forced. We left home.

From my experience, refugee is a status that, within the current panorama of world migration and immigration, is unique. Once this category or status is bestowed upon a person, it is never lost. Being a refugee is being part of a minority group within another minority group-that of immigrants. Being a refugee also means being in a factual struggle for freedom and dignity. This struggle is part of my past and current experiences and is carved in my personal and professional reality. It is this struggle that has informed my conviction that the figure of the refugee is the archetype of the twenty-first century-if not of humanity itself. This conviction stems from the historical and contemporary patterns of mass migration. My conviction hence points to the difficulties to find a place, in a moment in time in which people of all classes move around the world searching for "a better life." Refugees are forced into this search for refuge, for a home they have lost, for there is no life without refuge. Thus, this conviction asserts that the search "for a better life" starts as a search for refuge, for a safe place, a home to belong.

CATHERINE. In the spring of 1999 I received a call to come to the Red Cross office in downtown Halifax to help prepare for the arrival of 5,000 Kosovar refugees in what was dubbed Operation Parasol. ${ }^{1}$ Our team had extensive experience in domestic disaster response, but this kind of international response was unprecedented. Throughout the month of May, over 2,500 Kosovars arrived in Nova Scotia, and it was this experience that marked the beginning of my work in forced migration. I have so many heartfelt memories of the resilience of the Kosovar people and the humanity demonstrated by those directly affected and those in supporting roles. In a crisis, humanity can shine.

Fast forward to 2016: 20 June World Refugee Day. I took my ten-year-old son to a presentation at the Halifax Central Library called "Fleeing Home: Poetry on Persecution." A woman began to read her poetry, describing an extraordinary process of exile and identity formation. The poet was Yanery. A few months later, Yanery and I met during a participatory photography research project focused on the experiences of immigrant and refugee women. ${ }^{2}$ Yanery was a research participant and I was a volunteer researcher. We spent months together learning how to use photography to reflect on and teach about migration and settlement journeys. One particular experience resonated with both of us. After an emotional public presentation, showcasing the women's photographs and stories, an audience member asked us if we (society) should continue to use the term refugee, or if we (society) should consider a new word altogether. I have observed resistance to the term refugee, by refugees, because there are assumptions of vulnerability and lack of recognition of the multiple identities and labels embraced by and embodied on refugees. However, one research participant shared how the term was interconnected with the opportunities that arose from being a refugee, such as a full scholarship to university, and therefore it was a term that we (society) should not disregard for something new. Yanery agreed, and shared how for her, the term refugee stands for home, a concept that links the past, present, and future with the notion of safety and belonging. Yanery elaborated on the importance of keeping the word refugee, while emphasizing how essential it is that we (society) challenge, critique, and deconstruct what it means. It was this experience that led Yanery and me to further reflect on and work together to develop a deeper understanding of how refugee identities and labels are entwined.

\section{Our Approach}

YANery and Catherine. Full disclosure, we $e^{3}$ whole-heartedly agree with the UN argument that "migration is a fact of life in a globalized world, and the world is a better place because of it." 4 Migration is part of the fabric of Canadian history and is intimately entwined in the evolution of national labels. People have been moving to, from and within Canada for hundreds of years, and the positive socioeconomic and cultural impacts of migration are well documented. 5 This article focuses on those forced to migrate in an attempt to problematize the refugee label as a particular 
feature within migration and identity construction. In this article we question the word refugee as a category to qualify this diverse group of people by using narratives to examine how labels are constructed and how identity processes happen for, with, and in refugees. We focus on the social aspect of the refugee label, while recognizing it is both distinct from and connected to the legal status. Our objective is to deepen conversations among and between refugees, settlement practitioners, and the general public to further consider the complexities of identity, labelling processes, and the interconnections between them.

In this article we use our narrative stories to investigate our individual and collective processes of self-identification and labelling. We delve into the points where self-identification negotiates with labelling in order to conceptualize the notion of new spaces, where individual and collective refugee experiences mutually shape and transform each other. These new spaces emerge from an inclusive participatory socio-cultural and political process where the idea of "us" and "them" merges into "we." Our collaboration pushed our thinking about these concepts, and the following analysis is the culmination of this participation, which involved weekly conversations over the course of twelve months. We invite readers to respond to our reflections, stories, and questions and to further this important conversation.

\section{Social Complexities of the Refugee Label ${ }^{6}$}

CATHERINE and YANERY. Refugee is a socially constructed label with complex legal, ethical, and political connotations. Refugee, as a particular category, evolved in response to the mass displacement of people following the Second World War and stemmed from a state-centred mindset focused on population control.7 Scalettaris argues that responses to mass displacement, such as the post-Second World War efforts, illustrate how "labels account more for the historical, institutional context in which they are produced" and how "the interests of hegemonic states are the most powerful factor in shaping the policy framework for the management of human mobility, and, accordingly, in producing labels." Within the refugee regime, ${ }^{9}$ power is expressed in multiple ways, such as through policy and law, and these expressions of power influence how categories and labels are constructed. ${ }^{10}$ The contemporary refugee label, which attempts to group together an extraordinarily heterogeneous population of people, fails to nuance the diverse historical, social, political, and cultural contexts that drive forced migration. ${ }^{11}$ The contemporary refugee label also lacks an analysis of how power is expressed within the making and sustainment of that label. Malkki argues, "Involuntary or forced movements of people are always only one aspect of much larger constellations of sociopolitical and cultural processes and practices." ${ }^{12}$
Understanding how power operates within the refugee regime, and particularly in terms of the construction of the refugee label, can expose the socio-political motivations for constructing this label, and the consequential impacts and opportunities that it produces.

Even though the refugee label is contentious, it binds the people constructed and labelled within it; as Kumsa shares, "I am a refugee! Others look at me and see a refugee. I look at my Self through Others' eyes and become a refugee. The notorious cycle of Self is complete. The fact that I have been a Canadian citizen for over ten years matters little. Persecution and flight, asylum and resettlement, racialization and alienation, all woven into essentialist discourses of nationhood construct me as a refugee."13

In this reflection, Kumsa captures how power is expressed in labelling and effectively articulates the interaction between individual (agency) and collective aspects of labelling. In a similar vein, Basch, Glick Schiller, and Szanton Blanc observe, "Once people find themselves conceptualized and come to conceptualize themselves as bound together with a common situation or identity, distinctiveness does indeed arise." 14 This distinctiveness can manifest into $u s$, them, and other categorizations based on the historical and cultural dimensions of the time. For example, in the context of Malischewski's work in Northern Ireland, other, as a category, refers to refugees as a group of people with such diminished value that they are not legitimized as present or worthy of recognition in a social conflict. ${ }^{15}$ In this context, the label of other and the label of refugee come together to illustrate distinctiveness from the mainstream society. The label of other often stems from contrived and discriminatory narratives, which privilege those in power. ${ }^{16}$ Spivak named this process the "epistemic violence of othering" and emphasized the importance of exploring the politics embedded in processes of representation. ${ }^{17}$

Zetter takes up this notion of the politicization of representation and argues the refugee label has undergone significant transformations since the 1970s, when the "formation" of the refugee label focused on patterns of migration. ${ }^{18}$ Impacted by globalization, this approach connected "the refugee" to the causes of forced migration, and NGOs played a primary role within this phase. ${ }^{19}$ From its "formation," the refugee label was "transformed" to take into consideration the increased complexity of migration patterns, and, in response, the refugee label became part of a state-led migration management system. ${ }^{20}$ It was in this phase that Catherine entered the world of forced migration. Operation Parasol serves as an excellent example of the transformation from NGO-led to state-led responses to forced displacement. While NGOs played a prominent role in this response, it was the Canadian government, in partnership with other states, that managed the response. 
The refugee label within this transformation stage is based on the norms and discourses of state leaders; norms and discourses that often change with the introduction of new leadership. Additionally, these state-centred responses to the plight of refugees often encompass contradictory nationalist notions of humanitarianism. For example, in the mid1980 os the Mulroney government promoted a humanitarian agenda stating, "If we err ... we will always err on the side of justice and on the side of compassion," ${ }^{21}$ while simultaneously implementing Bill C-84, the Refugee Deterrents and Detention Bill, granting Canadian authorities the ability to turn away ships suspected of carrying asylum seekers. ${ }^{22}$ The arrival of two ships in 1986, one carrying Tamils and the other carrying Sikhs, resulted in an enhanced exclusionary state approach to forced migration and illustrates the kind of "fences and walls" being erected to prevent migration from sites of unrest and conflict in order to manage migration patterns. ${ }^{23}$ Harrell-Bond describes how the building of "visawalls" by states (both metaphorically and physically in the case of Greece and Israel) substantially contributes to precarious and unsafe migration and is fuelled by this Northern hegemonic ideology of humanitarianism. ${ }^{24}$ These statecentred hegemonic ideologies of humanitarianism have led to diminished protections afforded to refugees. ${ }^{25}$

The $\mathrm{UN}^{26}$ argues, "This is another time in which a toxic, xenophobic and often racist narrative is taking hold in many parts of the world." This emerging "toxic" narrative is deeply intertwined with the politicization of the refugee label. The key features of this contemporary politicized refugee label include the source of the labelling process-states-as well as the efforts to disconnect refugees from the notion of international protection. ${ }^{27}$ "Illegal migrants," "bogus claimants," and "queue jumpers" are the labels often used by states to dehumanize refugees and to garner support for securitized refugee policies. Chimni argues the transition from NGO to state-led intervention during times of large population movements, including the engagement of the un Security Council and NATO, has contributed to the normalization of the "language of security" and the destruction of refugee rights. ${ }^{28}$ These politicized and securitized processes are evident in the discrepancies between asylum policies and states' promotion of human rights. ${ }^{29}$ For example, Canadian prime minister Justin Trudeau failed to show a clear position and sound plan to process the cases of more than 10,000 asylum seekers moving from the United States and Haiti in the summer of 2017. This led to criticism from the Conservative Party, judging Trudeau's response as too lax, while, on the other hand, the prime minister was criticized by the NDP for the exact opposite reasons, as his response was considered as not being humanitarian enough. ${ }^{30}$ Kumsa contends that this politicized and securitized approach to forced migration, "constructs 'the refugee' as a strong antithesis of the nation ... the dangerous roamer and unattached wanderer." ${ }^{1}$

\section{Problematizing the Refugee Label}

CATHERINE. I have worked in forced migration for nearly two decades, learning from and with people who have come to Canada seeking safety and protection. My professional practice has involved supporting people to reconnect with family members separated by humanitarian crises, facilitating public education on migration issues, and establishing enhanced settlement practices and policies - largely based on the experiences of refugee women..$^{32}$ During this time, I have observed the increasingly politicized and securitized transformations of the refugee label within government, the media, and public discourse on migration. I have witnessed the transition of refugees as "thieves" (stealing jobs) to refugees as "terrorists" on a mission to destroy Canadian values.

I remember walking into a corner store with a family from Kosovo in 1999. An elderly gentleman approached us and under his breath he said, "We don't have enough jobs for Canadians. We need to look after our own first. Tell them to go home." Unfortunately, I continued to be inundated with similar messages about job security and the economy, despite the positive Canadian peacekeeping and humanitarian narratives being promoted at the time. At the time of writing this article, the labels seem to have become even more antagonistic and securitized. In fact, the value of the other (i.e., refugees) is no longer partial or less than the mainstream community; the other has become dangerous, and this danger narrative has been institutionalized within Canadian and international policies, often resulting in the failure to recognize the humanity of refugees. The 2012 reduction in health care afforded to refugees in Canada, and the subsequent ruling 33 that these reductions were "cruel and unusual," serves as a stark example of the impact and reach of the danger narrative. ${ }^{34}$ Even within Prime Minister Trudeau's seemingly pro-refugee actions during the Syrian response in 2015-16,35 the exclusion of single men from Canada's resettlement program offers another illustration of how the dangerous other narrative filters into policy.

Beyond the danger (harmer) narrative, which focuses on the risks associated with forced migration in public safety and economic burden, there is another predominant forced migration narrative-the helpers. The helpers focus on the vulnerabilities of refugees and the importance of helping, of doing the right thing. Regardless which narrative one may align with the most (recognizing this duality is overly simplistic), each involves the objectification of refugees and a labelling in which those fleeing crises are seen as objects either requiring help or posing a threat, and not as subjects with agency and voice. ${ }^{36}$ 


\section{Refugee Labels \& Identities}

YANERY. I was eleven years old when I left my little hometown to go to school. This is how my story of migration started, a story that is deeply ingrained in my identity and in who I am today. Every dimension of my social life was touched by migration. I came of age during the perestroika, which marked ten brutal years in the identity of all those who, like me, were living the agony of a country petrified by fear. It was during this period that my desire to leave Cuba first emerged.

I remember leaving Cuba at five in the afternoon, the red dust shaking the palm crests around the Havana airstrip. I arrived in the evening to a sea of lights within which a city lay lost. I landed in Mexico. The fact that I left my family, my friends, and my land at the age of twenty, with no idea as to whether I would be able to come back to them, powerfully triggered my need to build and sustain spaces in Mexico to express my Cuban identity, or, as they call it back home, my cubanía. Soon after I arrived, I felt my cubanía everywhere I went; yet I felt a similar trigger to absorb and learn the Mexican identity and to make it part of my own. In this constant transformation, my transnationalism was born. I thus became a transmigrant. My life is shaped by the links I made through my transnational identity between Cuba and Mexico, going back and forth from one place to the otherand belonging in them both.

Conversely, my arrival in Canada in 2007 was accompanied by the realization that there was no going back. This realization informed a forced settlement. In those days, my identity fell behind my physical integrity, which was literally obstructed by the domestic violence and political persecution that eventually became the causes behind my asylum claim. Such obstruction exhausted my sense of personhood, my life as a citizen, and my sense of belonging. I was not able to appease a horror that I carried inside me at all times, which was separated only by a geographical distance. As the process of asylum seeking took root, and as I started to receive support (more or less effectively, but support nonetheless) from government, NGOs, civil society, and personal relations, my identity started to settle again. I lost interest in being from here or there. I rediscovered a world that was multifaceted, multi-faced, multilingual, diverse, and cosmopolitan. This world opened a space for me, that new space 37 to fix and save those parts of my identity that were still alive, my inborn cubanía and my more recently acquired mexicaneidad.

Since I presented my case to the Canadian authorities and became an asylum-seeker, I have never felt dishonoured to bear the label of refugee-even if I have met the barriers, stigma, and discrimination that this label bears. I am proud to be a refugee, as I have reconciled with what happened to me. Yet I have never experienced the emotion of hearing from another refugee, "Oh! You are a refugee. I am a refugee too!"

Being a refugee means being in a contradiction: it means being vulnerable and having to show this vulnerability in order to receive protection, while, on the other hand, having to show resilience. Although I am proud of having received protection, I understand the complexities of the vulnerability-resiliency contradiction. There is no pride in being vulnerable, or in having to show it, particularly when everyone keeps stressing how resilient you are. And this is the essential contradiction that most refugees face.

Despite this contraction, as refugees and asylum seekers we carry our self-respect and the multiple causes that brought us to where we are today. Hence, we seek a platform to show our worth as human beings. And we seek it in our everyday lives, trying to find a balance between our private worth and the possibility of creating a new space to live in. This new space is not just physical; it is a space of reconciliation and identification that is constructed in each person and is shaped by mundane struggles throughout the sociocultural and political processes that lie beneath the refugee label. This new space should foster a continuous updating of the refugee label.

\section{Complexities, Opportunities, and Tensions}

YANERY and CATHERINE. The pronoun we plays a key role in what a refugee represents, regardless of who bears the label. We are all interconnected and affected by each other in this "we," and thus we all need to know how the refugee label affects our human experience. We also need to understand how we respond to the values and interests that contribute to the formation of this label.

Bridget Hayden argues it is possible to understand this contentious term (refugee) by focusing on the converging point that the "we" opens for "us and them" (non-refugee and refugee), wherein "the recognition of refugees is the recognition of mutual bonds of humanity and need," 38 as embraced, ideally, by everyone. This recognition stems more from the responsibility we bear to each other than from the rights we are entitled to or the duties we are compliant with as individuals. Framing forced migration as a co-responsibility allows us to realize the importance of observing, analyzing, and participating in the construction of the refugee label. The ways in which the term refugee is constructed, both as a legal status and a label, shows our social awareness, our political vision, and our moral values. However, when it is exclusively dictated and informed by "us" (non-refugees), this term fails to reflect the "we." Thus, we propose that non-refugees need to engage with refugees in a mutual identification to learn together how labels and identities are constructed. And this can be done within the possibilities that the "we" opens for us. 
When the "we" is used in labelling, there is an implicit link between structure and agency. This link is central in Roger Zetter's work in refugee studies. ${ }^{39}$ For Zetter, the structure corresponds to regulatory bodies upon which labels are institutionalized, while agency corresponds to the individual and the individual's identities. When this link is dislocated, the label becomes more structure than agency, that is, the label is used as an othering factor that is externally attached to the refugee. ${ }^{40}$ In this way, humanitarianism is the by-product of bureaucratic institutions exerting a label, and the label is hence at the service of these institutions, or, what Zetter calls "institutional agency." ${ }^{11}$ The protective blanket thrown over the refugee label ends up becoming a "curtailment of their rights." ${ }^{2}$ A label produced in this manner functions as an instrument of control, where institutionalization factors the assumptions and expectations that abrade the identity of those to whom the label "refugee" is attached-even before they acquire such status and/or arrive into their host countries. 43

The balance between "us" and "them" is frail-even more so in the global world in which we live. Within our globalized world, each person, refugee or not, is able to assign or attach a label to a refugee. The legal status of the refugee, however, is granted or denied despite the fact that there may or may not be a label in place for this status. This is to say that the legal status always supersedes the label, even if the label is often applied by the authorities that grant or deny the status. ${ }^{44}$ In this manner, structure keeps overriding the agency (i.e., identity) of those to whom the label is attached. For Zetter, this process is subjected to three axioms: formation, transformation, and politicization. 45 Yet, despite how oppressive or alien the label may be, we claim that agency is never completely lost. ${ }^{6}$ Once refugees have acquired this status, there is the possibility of activating, for better or worse, a refugee identity that affirms their agency and, through it, their participation in the construction of this label.

In contrast to a label, identity is the possibility of imagining the "I" in the context of both individual and collective processes. Identity carries narrated processes of self-identification that vary significantly across multiple contexts, within which migration is a significant one. Stuart Hall refers to this variation as "cultural identities ... which are constantly producing and reproducing themselves anew, through transformation and difference." 47 Identity-formation never points at one affixed identity, but rather outlines a developmental flow that evolves as a story does. We narrate our stories to illustrate the process of identity-formation from the perspective of being a refugee ("them") and becoming a Canadian "we," as well as from being a Canadian ("us") and becoming a "we."

Identity, and its fluid process of transformation, is subject to interact with previously established labels. This is the case with the identity of the refugee. When those labels are externally attached to the person who is just arriving into the legal status, this person is entered into the story as the protagonist. Being situated in an alien story, as the protagonist, hinders the fluidity of the process of identity-formation. This obstruction leaves only a figurative, alien space to which the new refugee does not yet belong, despite having been attached to a literal label. Therefore, identity is a key piece in the adaptation and integration of a refugee, as it continuously strives against the previously established and attached label.

Change and transformation are central to identity-formation for refugees. This process goes hand-in-hand with the diversification of our national spaces and our spaces of self-identification. Our roots proliferate into different spaces as multiple stories converge into the main narrative of our lives. There is a sort of haven that opens in between this process of diversification, which allows for a different kind of space to take root-a new space. This new space can allow for an identity development that aligns with a cosmopolitan society, a self-identification that represents the kind of place where the "we" can emerge and engage in a collective dialogue from which an inclusive label can emancipate itself. It is close to what Sally Munt calls "temporary spaces [created to provide] a brief microcosm of home, and a strong sense of collective engagement." 48 This space is thus the ground for transcultural and transnational integration. The space of the "we" exists both inside and outside of oneself. It is an imagined and internalized identity in a dialogical correspondence with conflicting ways of life, which simultaneously shapes one's experiences. In this new space, refugees can be globalized and individualized all at once. However, for this space to open, it is necessary for the refugee to arrive in a plural place.

YANERY. This is what I am most appreciative about Canada. Since the beginning, it was a place that afforded me with the possibility of solving the innermost complexity of the refugee status: being forced to live in a place that you want to become a part of because you know there is no other option and there is no way back. It was in Canada that I lost my need to show my cubania and my mexicaneidad everywhere I went. Instead, the ability to be simultaneously from here and there enabled me to embrace a kind of world citizenship. And this I owe to Canada, a place that in its being multi- exempts me from the necessity of defining myself as only-. Often I feel my cubania, my mexicanidad, and my canadienship coming all in waves, all at once, and it is difficult to find where one ends and the other one begins. It is the proliferation of the one.

\section{We and Spaces: Discussion and Analysis}

YANERY and CATHERINE. Refugees share a history of surviving violence, embarking on a "dangerous journey," and living 
through "precarious arrivals and uncertain reception" in a new country; 49 and yet there is no singular formula that describes how refugee identities and labels are constructed. Narratives that describe refugee experiences, which are paramount to identity-formation, can become part of the analysis of how labelling operates. Thus, we frame our analysis on the predication that labelling is a socio-political process, which both influences and is influenced by refugee identities.

Refugee identities are extremely diverse and steeped in contradictions, which include the entangled relation between vulnerability and resiliency. Refugee identities are also characterized by a combination of fluidity and obtrusion, a combination that ideally culminates in an "identity stabilization." 50 Labels, on the other hand, are the culmination of socio-political power that produces and sustains categorizations or groupings of people..$^{51}$ Refugee labels are constantly evolving and transforming within an increasingly politicized and securitized socio-political context, and they are informed as much by those who bear the label as by those who do not. Within this socio-political context, refugee identities and labels are imprinted onto one another and form a complex web of collective and individual transformations. It is in this process that identity and labelling can influence each other. Analyzing the intersections between refugee labels and refugee identity(ies) can enhance our understanding of broader forced migration processes, recognizing that they are neither exclusively individual nor solely collective. We suggest more research is needed to explore the relationship between labels and identity, especially recognizing there is not one narrative that embraces the complexity, diversity. and variability that human movement and mobility entail today.

Stuart Hall defines cultural identity as a matter of "becoming" as well as a matter of being. ${ }^{52}$ Within this definition, identity formation is as much a process as it is something given. This is even more telling when identity is thought of as something that is given from a certain position, or, in Stuart Hall's words, "We all write and speak from a particular place and time, from a history and a culture which is specific. What we say is always 'in context,' positioned." 53 When positions are conceived of as something that is both a process (i.e., in context) and a given (i.e., place and time), then they can be approached as being fluid and mutable. ${ }^{44}$ In this manner, refugees can be recognized and approached as having the capacity to activate and integrate a new space in the particular place and time they arrive in, hence opening a new position in their host country.

During the process of becoming and being, refugees evolve in new spaces, establishing new positions, locations .and representations. In this way refugees can better adapt to and influence the contexts where they arrive as well as in the social representations that predate them. This process delineates their participation in a global space that helps them to demystify the cultural isolation, extreme vulnerability, trauma, and victimization that often characterize the labels that are attached to them. Most of these characterizations owe much to the fact that refugees are perceived and positioned as being new, almost as though they were newborn beings. In spite of the specificities and unique aspects of each cultural group, refugees are not new to the world, even less so in a globalized one, and especially considering the extreme resiliency expected from refugees to persevere during and beyond their precarious journeys. 55 Thus, we have aimed to show that refugees need to be able to co-create a new space where they can exercise and share their agency, capacities, and vulnerabilities with those already living in the space that hosts them. Refugees hence must be co-creators of a new space where labels can be deconstructed and transformed to emphasize a shared humanity.

On the one hand, forced migration exposes horrendous injustices, our failure to live together peacefully, and our inability to respect difference. On the other hand, forced migration reveals tremendous resiliency and opens opportunities to build peaceful communities together. Creating new spaces within existing spaces opens the possibility for shared agency, allowing refugees to actively participate in determining possible actions and collective social norms. Typically, actors within existing spaces decide what is best for refugees and the broader community (helpers and harmers), instead of opening these spaces to co-decide their new position with all the participating actors. New spaces, where collaborative living is fostered, can reduce the constant sense of compromise endured by refugees as they encounter existing spaces, actors, and norms.

With this in mind, it is important to put newness, the refugee's perennial companion in both identity and label, in proper perspective. This newness often inspires a sense of protection by states and is "not only marred with negative connotations but it also inflicts the violence and pain of exclusionary practices."56 Indeed, refugees are not new. This idea of newness stems from a place of disruption and discrimination in helpers and harmers, who, perhaps in different ways, equally objectify forced migrants. What is new is the context the refugee enters, and this context is not exclusive to the refugee; this context also includes the existing actors and receiving parties (refugee sponsors, for example), as the context is new for them as well. The new space is founded upon a layer of each member's identity, refugee or not. Thus, this space requires neutrality where all members have opportunities to grow and where interconnectedness can be nurtured; where "we" are "being" and "becoming" together. This new space is not a utopia; it is a space where 
"we," as a society, embrace the responsibility for each other. Are "we" ready for that?

\section{Notes}

1 In 1999 UNHCR asked several countries to provide a safe place for over 100,000 Kosovar refugees, and 5,000 Kosovars came to Canada.

2 The Women Speaking through Photography Collective is led by Dr. Susan Brigham at MSvu in Halifax, Nova Scotia. Susan Brigham and Women Speaking through Photography Collective, "Re-signifying to Engaging" (presentation at the Young Immigrant and Refugee Women Learning in Community to Adult Education Conference, University of New Brunswick, 14-16 October 2016).

3 We use an italicized we to signify collaboratively written portions of our article.

4 United Nations, New York Declaration for Refugees and Migrants, 2016, 3.

5 See Statistics Canada, Immigrant Economic and Social Outcomes in Canada (Ottawa: Government of Canada, 2011); United Nations General Assembly, In Safety and Dignity: Addressing Large Movements of Refugees and Migrants (New York: Un, 2016). Although the long-lasting effects of the forcible displacement of Indigenous peoples are also well documented, this article focuses on forced migration and immigration, which does not deal with the colonial figure of the settler. For further commentary on the effects of forcible displacement of indigenous peoples, see Daniel N. Paul, We Were Not the Savages (Halifax: Fernwood Publishing, 2008).

6 We intentionally chose to use the word label, for as Zetter explains, this word "recognizes both a process of identification and a mark of identity; implies something independently applied, but also something which can be chosen and amended." Roger Zetter, "More Labels, Fewer Refugees: Remaking the Refugee Label in an Era of Globalization," Journal of Refugee Studies 20, no. 2 (June 2017): 172-92.

7 Audrey Macklin, "Historicizing Narratives of Arrival: The Other Indian Other," University of Victoria, 2006.

8 Giulia Scalettaris, "Refuge Studies and the International Refugee Regime: A Reflection on a Desirable Separation," Refugee Survey Quarterly 26, no. 3 (January 2007): 36-50.

9 The refugee regime refers to the creation of UNHCR and the 1951 Convention on the Status of Refugees and, in words of Betts, the "institutionalized cooperation in the area of human mobility." Betts argues the refugee regime complex is a more comprehensive and contemporary term, given the increased institutional involvement in forced migration. Alexander Betts, "The Refugee Regime Complex," Refugee Survey Quarterly 29, no. 1 (January 2010): 12-37.

10 James Milner and Krystyna Wojnarowicz, "Power in the Global Refugee Regime: Understanding Expressions and
Experiences of Power in Global and Local Contexts," Refuge 22, no. 1 (2017): 7-17.

11 Liisa Malkki, "Refugees and Exile: From 'Refugee Studies' to the National Order of Things," Annual Review of Anthropology 24 (January 1995): 495-523.

12 Malkki, "Refugees and Exile," 496.

13 Martha Kuwee Kumsa, "No! I'm Not a Refugee! The Poetics of Be-Longing among Young Oromos in Toronto," Journal of Refugee Studies 19, no. 2 (June 2006): 230-55.

14 Linda Basch, Nina Glick Schiller, and Christina Szanton Blanc, "Transnational Project: A New Perspective' and 'Theoretical Premises," in The Transnational Studies Reader, ed. Sanjeev Khagram and Peggy Levitt, 261-72 (New York: Routledge, 2008).

15 Charlotte-Anne Malischewski, "Refugee at the Crossroads: Social and Territorial Dynamics of integration in Northern Ireland," in After the Flight: The Dynamics of Refugee Settlement and Integration, ed. Morgan Poteet and Shiva Nourpanah, 21-42 (Newcastle: Cambridge Scholars Publishing, 2016).

16 Edward Said, Orientalism (New York: Random House, 1978); Audrey Macklin, "Historicizing Narratives of Arrival: The Other Indian Other," University of Victoria, 2006.

17 Gayatri Spivak, The Post-colonial Critic: Interviews, Strategies, Dialogues (New York: Routledge, 1990).

18 Zetter, "More Labels, Fewer Refugees."

19 Zetter, "More Labels, Fewer Refugees."

20 Zetter, "More Labels, Fewer Refugees."

21 Joe O'Donnell, "Show Compassion for Tamil Refugees, Mulroney Urges," Toronto Star, 18 August 1986.

22 Valerie Knowles, Strangers at Our Gates: Canadian Immigration and Immigration Policy, 1540-2007 (Toronto: Dundurn, 2007).

23 United Nations, New York Declaration for Refugees and Migrants, 2016.

24 Barbara Harrell-Bond, "Government and Civil Society Cooperation to Protect Refugee Rights and Development," Asian Journal of Peacebuilding 1, no. 1 (May 2013): 129-38.

25 B.S. Chimni, "Globalisation, Humanitarianism and the Erosion of Refugee Protection," Journal of Refugee Studies 13, no. 3 (September 2000): 243-63.

26 United Nations General Assembly. In Safety and Dignity: Addressing Large Movements of Refugees and Migrants (New York: United Nations, 2016).

27 Zetter, "More Labels, Fewer Refugees."

28 Zetter, "More Labels, Fewer Refugees."

29 Bridget Hayden, "What's in a Name? The Nature of the Individual in Refugee Studies," Journal of Refugee Studies 19, no. 4 (December 2006): 471-87.

30 For further commentary on the "open borders" misunderstanding that is sending Haitians living in the United States to cross the Canadian border in Quebec, see Geoff Robins, "False Information Sends Asylum-Seeking Haitians to Canada," Globe and Mail, 6 August 2017. On criticism 
against Trudeau's response to the asylum seekers' situation in the Canadian border, see Stephanie Levitz, "NDP MP Says Trudeau Liberals Misleading Asylum Seekers over Border Crossings," Global News, 23 August 2017.

31 Kumsa, "No! I’m Not a Refugee!"

32 Catherine Baillie Abidi, "Invisible Women, Concrete Barriers: Policy Roundtable on Issues Facing Refugee Women" (paper presented at the Atlantic Centre of Excellence for Women's Health, the Canadian Red Cross, Atlantic Council for International Cooperation, and policy roundtable participants, Halifax, 6 March 2008).

33 In 2014 Justice Mactavish ruled that reductions in health care afforded to refugees was "cruel and unusual treatment" because it intentionally targeted vulnerable populations. Fred Chartrand, "Ottawa's Refugee Health-Care Cuts 'Cruel and Unusual,' Court Rules," Globe and Mail, 4 July 2014.

34 Canadian Doctors for Refugee Care, the Canadian Association of Refugee Lawyers, Daniel Garcia Rodriques, Hanif Ayubi, and Justice for Children and Youth vs. Attorney General of Canada and Minister of Citizenship and Immigration, Court order, 4 July 2014, 1080.

35 Between November 2015 and February 2016, Canada resettled 25,00o Syrian refugees. Peter Zimonjic, “25,00o Syrian Refugees Have Landed, Now for Phase 2, Says John McCallum," Globe and Mail, 29 February 2016.

36 Bernadette Ludwig, "Wiping the Refugee Dust from My Feet: Advantages and Burdens of Refugee Status and the Refugee Label," International Migration 54, no. 1 (February 2013): 5-18.

37 The conceptualization of this "new space" is key to the argument of this article. This conceptualization will be further developed below.

38 Hayden, "What's in a Name?"

39 Zetter, "More Labels, Fewer Refugees."

40 Zetter, "More Labels, Fewer Refugees," 173-4.

41 Zetter, "More Labels, Fewer Refugees," 175.

42 Chimni, "Globalisation, Humanitarianism and the Erosion of Refugee Protection."

43 Chimni, "Globalisation, Humanitarianism and the Erosion of Refugee Protection."

44 The 1951 Geneva Convention defines a refugee "as a person who is outside his or her country of nationality or habitual residence; has a well-founded fear of being persecuted because of his or her race, religion, nationality, membership of a particular social group or political opinion; and is unable or unwilling to avail him-or herself of the protection of that country, or to return there, for fear of persecution" (see article 1A(2)). United Nations High Commissioner for Refugees, The 1951 Convention Relating to the Status of Refugees and Its 1967 Protocol, http://www.unhcr. org/about-us/background/4ec262df9/1951-conventionrelating-status-refugees-its-1967-protocol.html.

45 Zetter, "More Labels, Fewer Refugees," 174. These three axioms were conceptualized above.

46 I, Yanery, have attempted to illustrate this claim through my voice.

47 Stuart Hall, "Cultural Identity and Diaspora," in Identity, Community, Culture, Difference, ed. Jonathan Rutherford, 222-37 (London: Lawrence \& Wishart, 1990).

48 Sally Munt, "Journeys of Resilience: The Emotional Geographies of Refugee Women," Gender, Place \& Culture 19, no. 5 (September 2011): 555-77.

49 United Nations, New York Declaration for Refugees and Migrants. NY: United Nations, 2016.

50 James Baker, Chris William Martin, and Jonathan Price, "Becoming 'Nagarikharu': Unsettled Lives and Identity Formation among Bhutanese Refugees," in After the Flight: The Dynamics of Refugee Settlement and Integration, ed. Morgan Poteet and Shiva Nourpanah, 1-20 (Newcastle: Cambridge Scholars Publishing, 2016).

51 James Milner and Krystyna Wojnarowicz, "Power in the Global Refugee Regime: Understanding Expressions and Experiences of Power in Global and Local Contexts," Refuge 22, no. 1 (2017), 7-17.

52 Hall, "Cultural Identity and Diaspora," 222 (emphasis in original).

53 Hall, "Cultural Identity and Diaspora."

54 Hall, "Cultural Identity and Diaspora."

55 Riley L. Smith, "Female Refugee Networks: Rebuilding Post-Conflict Identity," International Journal of Intercultural Relations 37, no. 1 (January 2013): 11-27.

56 Kumsa, “No! I’m Not a Refugee!” 240.

Yanery Navarro Vigil is a full-time PhD student, Mount Saint Vincent University. The author may be contacted at Yanery .Navarrovigil@msvu.ca

Catherine Baillie Abidi is part-time faculty, Mount Saint Vincent University. The author may be contacted at Catherine .Baillie@msvu.ca 